\title{
Effect of Different Rice Varieties and Synthetic Insecticides on the Population Density of Rice Stem Borer Scirpiophag incertulus (Lepidoptera: Crambidae)
}

\section{Hussain Ali1 ${ }^{1}$, Shahid Sattar Khan ${ }^{1}$, Fazal Maula ${ }^{2}$, Said Hussain Shah ${ }^{3^{*}}$ and Misbah Uddin ${ }^{1}$}

${ }^{1}$ Department of Plant Protection, Faculty of Crop Protection Sciences, The University of Agriculture Peshawar, Pakistan; ${ }^{2}$ Entomology Section, Agriculture Research Institute Mingora Swat, Pakistan; ${ }^{3}$ Insect pest Management Program, institute of Plant and Environmental Protection, National Agriculture Research Centre, Islamabad, Pakistan.

\begin{abstract}
Rice stem borer (Scirpophaga incertulas) infest the plants from seedling to maturity, which is one of the key pests that infest the rice crop at regular intervals. It is pivotal to find out management strategies for this pest for higher production of rice. Research experiments were conducted to investigate the impact of different rice varieties and synthetic insecticides on the population density of rice stem borer. Experiments were conducted in randomized complete block design (RCBD) repeated three times. The results revealed that the minimum population density of dead hearts $(3.50 \%)$ and white heads $(7.08 \%)$ were recorded in Fakher Malakand variety, while the maximum population of dead hearts (7.89\%) and white heads (13.7\%) were observed in JP-5 variety. Yield analysis showed that maximum yield $\left(2780 \mathrm{~kg} \mathrm{ha}^{-1}\right)$ was recorded in the Fakher Malakand variety. Data regarding the efficacy of different insecticides showed that maximum percent biological efficacy against rice stem borer (52.21\%) was observed in Lambda-cyhalothrin, while minimum percent biological efficacy against rice stem borer (14.91) was recorded in Lufenuron. In case of the insecticides, minimum yield $\left(1790 \mathrm{~kg} \mathrm{ha}^{-1}\right)$ was recorded in control plot, while maximum yield $\left(1875 \mathrm{~kg} \mathrm{ha}^{-1}\right)$ was obtained from plots treated with Lambda-cyhalothrin. To achieve optimum production, our findings highlighted the importance of properly integrating resistant cultivars and chemical management techniques for rice stem borers. Received | October 01, 2021; Accepted | February 10, 2022; Published | February 24, 2022

*Correspondence | Said Hussain Shah, Insect pest Management Program, institute of Plant and Environmental Protection, National Agriculture Research Centre, Islamabad, Pakistan; Email: hussainshah1421@aup.edu.pk

Citation $\mid$ Ali, H., S.S. Khan, F. Maula, S.H. Shah and M. Uddin. 2022. Effect of different rice varieties and synthetic insecticides on the population density of rice stem borer Scirpiophag incertulus (Lepidoptera: Crambidae). Pakistan Journal of Agricultural Research, 35(1): 105-114.

DOI | https://dx.doi.org/10.17582/journal.pjar/2022/35.1.105.114
\end{abstract}

Keywords | Rice varieties, Scirpophaga incertulas, Synthetic insecticides, Rice stem borer

\section{Introduction}

$\mathrm{R}$ ice (Oryza sativa L.) is important crop from Poaceae family. Rice contains about $7 \%$ protein $12 \%$ water and 75 to $80 \%$ starch (Oko et al., 2012; Hossain et al., 2015). In Pakistan, rice is grown on an area of about 3,034 thousand hectares with a production of 7,410 thousand tons and estimated yield of $2442 \mathrm{~kg}$ $\mathrm{ha}^{-1}$. The total area under rice cultivation in Khyber
Pakhtunkhwa is 61.6 thousand hectares with a production of 147.5 thousand tons and yield of $2103 \mathrm{~kg}$ $\mathrm{ha}^{-1}$ (MNFSR, 2019-20). The yield of rice per hectare in the province is lower than the country average yield and this may be due to various factors including limited experience of cultivation, environmental stress, improper management of insect pests and diseases etc. Insect pests are the major constraints in reducing the rice productivity, besides diseases and weeds 
(Behura et al., 2011) and around 21\% of the world's rice yield losses are linked to pest attacks (Yarasi et al., 2008).

In Pakistan 70 different species of insect pest on the paddy have been reported (Hashmi, 1994). Among these insect pests, stem borer of rice namely Scirpophaga innotata and Scirpophaga incertulas in South East Asia has been confirmed to be the pest with the highest rate of outbreaks, resulting in massive crop failure (Chakraborty, 2009). These borers vary in severity of damage and population intensity (Hashmi, 1994). Scirpophaga incertulas is one of the key challenges and yield limiting elements in rice fields which infest the plants from seedling to maturity (Sarwar, 2011). Scirpophaga incertulas is recognized as being one of the key pests that infest the rice crop at regular intervals and it is predicted that 25-30\% crop losses are attributable to this pest in Pakistan early in the season. The larval stages is an important stage in $S$. incertulas responsible for maximum infestation ( $\mathrm{Re}^{-}$ nuka et al., 2017).

The life cycle of stem borers is similar to other harmful insect pest of rice. Stem borer comprises four significant phases of life, including egg which turn into hatchlings, pupa and finally the adult. The female moth lays 50-250 eggs over the surface of plant leaves, generally on the lower side of leaf (Bashir et al., 2004). The eggs after laying are covered with web by female moth to avoid parasitism. At first, the larva start feeding only the tissues of upper phase of leaves but with time they reach the stem of the plant and start taking nutrients. This causes them to transform into pupal stage and most of them form cocoons during this phase but certain species lack this during their life span. The consequences of the assault by rice stem borers in many crops mainly in the rice are labeled and signified by the dead hearts and white heads in first stage and later the panicle get infested (Alvi et al., 2003).

Insecticides are a practical way to control insects. Insecticide use has a positive effect on rice production (Abro et al., 2013). Such control not only have destructive consequences for natural environment but also make the pests resistant with time. Safe steps to stop these insecticides are, however, the production of crops with their own mechanism of resistance against these pests (Ahmad et al., 2011). The cultivation of herbicide and pest-resistant rice cultivars has prov- en to be the most cost-efficient, safe, and successful method of controlling weeds, diseases, and pests (Divya et al., 2018). A great number of genes originating from rice and microorganisms with resistance to borers are currently available, making it easier to create and nurture multiresistant rice types to control weeds, pests, and diseases in a more cost-effective, environmentally benign manner (Duke et al., 2008).

The application of pesticides or the development of resistant types are the most effective ways to manage diseases and pests, but excessive pesticide use will definitely contaminate rice products and the environment (Skamnioti et al., 2009). With the production of such resistant genotypes rice crops, the quantity of insecticide use has declined (Catindig et al., 2009). For integrated pest management, recognition of such resistant genotypes is critical. In contrast to many other non-resistant varieties, fewer insect pest attack the crop and also the formulation of pesticide were applied to these crops because of the resistant crops (Khan et al., 2005).

There are numerous plant attributes that are dependable for host plant confrontation. The plant constituents may manipulate negatively as well as positively on herbivore and their natural opponents (Krips et al., 1999). These attributes may be separated into morphological and biochemical where morphological features are most significant in host plant resistance (Parvez et al., 2000). These characteristics are important in the rice crop because they determine a cultivar's suitability for rice stem borer, development, and oviposition. To lower the presence of stem borer in rice crops, environmentally and economically effective management techniques will be necessary (Daware et al., 2011). The natural varietal resistance in rice, insecticidal treatment for the management of various insect pest assaults is a better alternative if done at the correct time and utilizing scientific techniques. More trials are needed in the investigation on the rice stem borer in Khyber Pakhtunkhwa.

\section{Materials and Methods}

Research experiments were conducted to investigate the impact of various rice varieties and synthetic insecticides on the population density of rice stem borer Scirpophaga incertulas in Agriculture Research Institute (ARI) Mingora, Swat, during 2020, Khyber Pakhtunkhwa. 
The response of different rice cultivars against rice stem borer

The rice cultivars, V1 (Swat -2014), V2 (Basmati 385), V3 (Dill Rosh-97), V4 (Kashmir Basmati), V5 (Fakher Malakand), V6 (Lawingi), and V7 (JP-5) were collected from the rice section of the Agriculture Research Institute (N), Mingora, Swat. The design used for this experiment Randomized Complete Block Design (RCBD) and each data values were taken in triplicates in order to minimize standard error. Thirty days old nursery was transplanted in the experimental subplots in a plot size of $4 \times 6 \mathrm{~m}^{2}$. Each plant was $20 \mathrm{~cm}$ distant, and each row was $20 \mathrm{~cm}$ off from each other. Agronomic standard practices were used throughout the cropping seasons.

\section{Effect of different insecticides against rice stem}

This experiment was conducted to measure the effectiveness of various insecticides against rice stem borer on the JP-5 rice cultivar. The experiment comprised of five treatments i.e. four insecticides and one control. The insecticides and their dose used in the experiment were Lufenuron 5\% EC (2ml/1Lt water), Bifenthrin $10 \% \mathrm{EC}(2.5 \mathrm{ml} / \mathrm{Lt})$, Chloropyrifos $40 \% \mathrm{EC}(3 \mathrm{ml} /$ $\mathrm{Lt})$, and Lambda-cyhalothrin $2.5 \% \mathrm{EC}(3 \mathrm{ml} / \mathrm{Lt})$.

The JP-5 rice cultivar was obtained from the rice section and different insecticides were collected from the Entomology section of the ARI Mingora, (Swat). The thirty-day-old nursery was transplanted into the experimental sub-plots in plot size $4 \times 6 \mathrm{~m}^{2}$. During the vegetative stage of plant the larva of stem borer bore at the base of the mother plant, while they start bore at upper part of plant and bore towards the base of plant. Knapsack Sprayer was used for the application of the insecticides after reaching the ETL 3 to $5 \%$ at Crop, and it was thoroughly washed after application of each treatment. The insecticides were applied three times after transplantation of nursery as per recommended doses and directions (Abhinandan and Gupta, 2020).

\section{Recorded parameters}

The data were recorded on weekly basis from each sub-plot when dead hearts (DH) and white heads (WH) symptoms occurred after transplantation of the nursery till the crop harvesting.

1. Dead hearts (\%)

2. White heads (\%)

3. Yield $\left(\mathrm{kg} \mathrm{ha}^{-1}\right)$

4. Biological efficacy (for experiment No, 2 only)

\section{Dead hearts:}

Data were collected from each sub-plot on 10 randomly selected plants. The collected data were converted into percentage by using the following formula (Islam et al., 2013).

Percentage of dead hearts was calculated after booting stage;

$$
D H \%=\frac{\text { Number of Dead hearts }(\mathrm{DH})}{\text { Total Number of tillers }} \times 100
$$

\section{White heads:}

The white heads data were recorded from 10 randomly selected plants. The recorded data were converted into percentage by using the following formula (Islam et al., 2013).

The percentage of white heads was determined after the milking stage;

$$
W H \%=\frac{\text { Number of the White heads }(\mathrm{WH})}{\text { Total Number of tillers with panicels }} \times 100
$$

Yield:

Grains yield ( $\left.\mathbf{k g ~ h a}^{-1}\right)$ : Grain yields were recorded in each plot from three key rows and then converted into $\mathrm{kg} \mathrm{ha} \mathrm{h}^{-1}$ by using the following formula. (Sagoo et al., 2012).

Grains yield $\left(\mathrm{kg} \mathrm{ha}^{-1}\right)=\frac{\text { Grains yield in three main rows in each plot }}{\text { Row to row distance } \mathrm{x} \text { number of rows } \mathrm{x} \text { row length }} \times 10000 \mathrm{~m}^{2}$

Calculation of 1000-grains weight (g): Thousand grain weight was determined by counting 1000 grain in each plot, and then weighting with a digital balance.

\section{Biological efficacy:}

The biological efficacy of treatments for pest infestation was calculated by the following formula.

$$
\text { Percent (\%)decrease over the control }=\frac{A-B}{A} \times 100
$$

A: Total number of dead hearts and white heads in control plot; B: Total number of dead hearts and white heads in treated plot.

All the documented data of this experiment was 
analyzed by using the latest version of the software (STATISTIX 8.1). All means and ANOVA were differentiated using the LSD Test at $(\mathrm{P} \leq 0.05)$, as described by (Steel and Torrie, 1980).

\section{Result and Discussion}

Two experiments were performed in order to investigate the effect of different rice varieties and synthetic insecticides on rice stem borer (Scirpophaga incertulas) population at Agriculture Research Institute (ARI) Mingora Swat during summer 2020, illustrated the various results.

\section{Varietal Preference}

Percent mean number of dead hearts in different rice varieties: The data (Table 1 ) showed that mean percent of dead hearts was significantly different from each other in various varieties, where the highest mean percent of dead hearts $(7.89 \%)$ were observed on JP-5 variety followed by lawingi and Dill Rosh97 with $5.94 \%$ and $5.56 \%$ dead hearts respectively and with non-significant difference from each other, whereas lowest percentage of dead hearts (3.50\%) was found on Fakher Malakand.

Table 1: Mean percent of dead hearts in various rice varieties recorded at weekly intervals (31 July to 4 September).

\begin{tabular}{|c|c|c|c|c|c|c|c|}
\hline \multirow[t]{2}{*}{ Varieties } & \multicolumn{6}{|c|}{ Means dead hearts Population } & \multirow[t]{2}{*}{ Mean } \\
\hline & W1 & W2 & W3 & W4 & W5 & W6 & \\
\hline Swati-2014 & 0.67 & 1.67 & 3.00 & 5.00 & 7.00 & 7.67 & $4.16 \mathrm{c}$ \\
\hline Basmati-385 & 1.33 & 2.33 & 3.67 & 5.33 & 7.00 & 9.00 & $4.78 c$ \\
\hline Dill Rosh-97 & 1.56 & 2.67 & 3.33 & 5.67 & 7.67 & 9.33 & $5.56 \mathrm{~b}$ \\
\hline $\begin{array}{l}\text { Kashmir Bas- } \\
\text { mati }\end{array}$ & 1.67 & 2.67 & 3.67 & 5.33 & 6.67 & 8.33 & $4.72 c$ \\
\hline $\begin{array}{l}\text { Fakher } \\
\text { Malakand }\end{array}$ & 0.67 & 1.67 & 2.67 & 3.67 & 5.33 & 7.00 & $3.50 \mathrm{~d}$ \\
\hline Lawingi & 2.33 & 2.67 & 4.33 & 7.00 & 8.33 & 11.00 & $5.94 \mathrm{~b}$ \\
\hline JP-5 & 3.33 & 5.33 & 6.67 & 8.00 & 10.00 & 14.00 & $7.89 a$ \\
\hline Mean & 1.65 & $2.80 \mathrm{e}$ & $4.09 d$ & $5.71 \mathrm{c}$ & $7.42 \mathrm{~b}$ & $9.47 \mathrm{a}$ & \\
\hline
\end{tabular}

Means followed by different letter (S) are significantly different from each other ( $p \leq 0.05)$; LSD for Varieties: 0.6455; LSD for Weeks: 0.5976; LSD for Interaction: N.S.

Result for time intervals showed highly significant difference. Maximum number of dead hearts (9.47\%) was recorded on week 6 of data collection followed by week $5(7.42 \%)$ while the minimum number of dead hearts were noted on week 1 (1.65\%). Interaction (varieties $\mathrm{x}$ time intervals) results were non-significant.
Mean Percent of white heads in various rice cultivars The data (Table 2) showed highly significant variation among the varieties in response to white heads due to rice stem borer. Results showed that maximum mean percent of white heads (13.7\%) were observed on JP-5 cultivars followed by variety lawingi and Dill Rosh-97 with $12.58 \%$ and $11.29 \%$ respectively and however with non-significant difference between them. whereas lowest mean percent of white heads (7.08\%), were found in Fakher Malakand.

Table 2: Mean percent of white heads in various rice varieties recorded at weekly intervals (11 September to 2 October).

\begin{tabular}{llllll} 
Varieties & \multicolumn{4}{l}{ Means white heads Population } & Mean \\
& W1 & W2 & W3 & W4 & \\
Swati-2014 & $11.33 \mathrm{f}$ & $9.33 \mathrm{gh}$ & $7.50 \mathrm{ijk}$ & $6.67 \mathrm{kl}$ & $8.71 \mathrm{e}$ \\
Basmati-385 & $13.00 \mathrm{~cd}$ & $11.50 \mathrm{f}$ & $9.50 \mathrm{gh}$ & $7.83 \mathrm{ij}$ & $10.45 \mathrm{~d}$ \\
Dill Rosh-97 & $14.00 \mathrm{c}$ & $12.67 \mathrm{de}$ & $10.01 \mathrm{~g}$ & $8.50 \mathrm{hi}$ & $11.29 \mathrm{c}$ \\
Kashmir Basmati & $11.66 \mathrm{ef}$ & $10.00 \mathrm{~g}$ & $8.50 \mathrm{hi}$ & $6.83 \mathrm{jkl}$ & $9.25 \mathrm{e}$ \\
Fakher Malakand & $8.50 \mathrm{hi}$ & $7.50 \mathrm{ijk}$ & $6.50 \mathrm{kl}$ & 5.831 & $7.08 \mathrm{f}$ \\
Lawingi & $15.33 \mathrm{~b}$ & $14.00 \mathrm{c}$ & $12.00 \mathrm{def}$ & $9.01 \mathrm{gh}$ & $12.58 \mathrm{~b}$ \\
JP-5 & $16.50 \mathrm{a}$ & $15.33 \mathrm{~b}$ & $13.00 \mathrm{~cd}$ & $10.04 \mathrm{~g}$ & $13.70 \mathrm{a}$ \\
Mean & $12.90 \mathrm{a}$ & $11.47 \mathrm{~b}$ & $9.57 \mathrm{c}$ & $7.81 \mathrm{~d}$ &
\end{tabular}

Means followed by different letter $(S)$ are significantly different from each other ( $p \leq 0.05$ ); LSD for Varieties: 0.5709; LSD for Weeks: 0.4315; LSD for Interaction: 1.1417.

Results regarding the effect of times interval on white heads showed highly significant difference as shown (Table 2). Maximum percent of white heads (12.90\%) were noted on week 1 followed by week 2 with $(11.47 \%)$ while the minimum percent of white heads $(7.81 \%)$ were recorded on week 4 followed by week 3 with (9.57\%). The interaction between varieties and time intervals showed significant variation. Maximum percent of white heads (16.50\%) were recorded on week 1 in variety JP-5 followed by variety lawingi on week 1 (15.33\%), while (15.33\%) are recorded on week 2 respectively. While the minimum percent of white heads (5.83\%) were observed in Fakher Malakand on week 4.

Effect of rice stem borer on different rice varieties in terms of 1000-grains weight (g) and grains yield ( $\mathrm{kg} \mathrm{ha}^{-1}$ )

The data revealed the effect of rice stem borer on various rice varieties in number of 1000 grain weight showed statistical variation among the cultivars as shown (Table 3). Mean maximum thousand grains weight were calculated in Fakher Malakand (31.1g) 
followed by variety Swati-2014 and Kashmir Basmati with $28.03 \mathrm{~g}$ and $25.3 \mathrm{~g}$ respectively. While the mean minimum (11.1g) thousand grain weight were recorded on JP-5.

Table 3: Effect of rice stem borer on different rice varieties in terms of 1000-grains weight $(g)$ and grains yield $\left(\mathrm{kg} \mathrm{ha}^{-1}\right)$.

$\begin{array}{lll}\text { Varieties } & \begin{array}{l}\text { Yield } \\ 1000(\mathrm{~g})\end{array} & \begin{array}{l}\left(\mathrm{kg} \mathrm{ha}^{-1}\right) \\ \text { Swati-2014 }\end{array} \\ \text { Basmati-385 } & 28.03 \mathrm{ab} & 2338.02 \mathrm{~b} \\ \text { Dill Rosh-97 } & 16.80 \mathrm{c} & 2069.09 \mathrm{c} \\ \text { Kashmir Basmati } & 25.31 \mathrm{~d} & 1907.02 \mathrm{~d} \\ \text { Fakher Malakand } & 31.10 \mathrm{a} & 2295.07 \mathrm{~b} \\ \text { Lawingi } & 13.61 \mathrm{de} & 1829.04 \mathrm{a} \\ \text { JP-5 } & 11.10 \mathrm{e} & 1746.08 \mathrm{e} \\ \text { LSD } & 3.3746 & 109.26\end{array}$

Means followed by different letter (S) are significantly different from each other ( $p \leq 0.05)$.

The data revealed that the effect of rice stem borer on various rice cultivars in grains yield $\left(\mathrm{kg} \mathrm{ha}^{-1}\right)$ showed statistically significant difference from each other (Table 3). Mean maximum grain yield $\left(\mathrm{kg} \mathrm{ha}^{-1}\right)$ were found in Fakher Malakand (2780.4 $\left.\mathrm{kg} \mathrm{ha}^{-1}\right)$ followed by variety Swati-2014 and Kashmir Basmati with $2338.2 \mathrm{~kg} \mathrm{ha}^{-1}$ and $2295.7 \mathrm{~kg}^{-1}$ respectively, and with non-significant difference between them, whereas minimum $\left(1746.8 \mathrm{~kg}^{-1}\right)$ grains yield were observed in JP-5.

Effectiveness of different insecticides against rice stem borer

Mean percent of dead hearts after $1^{\text {st }}$ spray: The data (Table 4) showed that mean percent of dead hearts was significantly different from each other after $1^{\text {st }}$ application of treatments in rice crop. Mean maximum percent of dead hearts $(4.55 \%)$ were recorded on control plot followed by Chloropyrifos with $3.44 \%$ dead hearts. While mean minimum percent of dead hearts were recorded on Lambda-cyhalothrin with $1.44 \%$ dead hearts.

Results for time intervals showed highly significant variation where highest percent of dead hearts (3.96\%) were calculated on week 3 followed by week $2(2.80 \%)$ while lowest percent of dead hearts (1.63\%) were notated on week 1. Moreover, interaction (treatments $\mathrm{x}$ time intervals) results were non-significant.
Table 4: Mean stem borer infestation, dead hearts (DH) after $1^{\text {st }}$ spray application of different insecticides, in JP-5 rice cultivar during summer (31 July, 2020).

\section{Insecticides}

Weekly intervals Mean

Lufenuron 5\% EC

W1 W2 W3

Bifenthrin 10\% EC

$\begin{array}{llll}1.33 & 2.33 & 3.67 & 2.44 \mathrm{c}\end{array}$

Chloropyrifos 40\% EC

$\begin{array}{llll}1.00 & 2.00 & 3.33 & 2.11 \mathrm{c}\end{array}$

Lamda-cyhalothrin 2.5\% EC

$\begin{array}{lllll}2.33 & 3.30 & 4.67 & 3.44 b\end{array}$

Control

$\begin{array}{llll}0.50 & 1.67 & 2.16 & 1.44 d\end{array}$

Mean

$\begin{array}{llll}3.00 & 4.67 & 6.00 & 4.55 \mathrm{a}\end{array}$

1.63 c $2.80 b \quad 3.96 a$

Means followed by different letter $(S)$ are significantly different from each other ( $p \leq 0.05)$; LSD for Insecticides $=0.5615$; LSD for weeks: 0.4349; LSD for Interaction: N.S.

Table 5: Mean stem borer infestation, dead hearts (DH) after $2^{\text {nd }}$ spray application of different insecticides, in JP-5 rice cultivar during summer (13 August, 2020).

\begin{tabular}{lllll} 
Insecticides & \multicolumn{3}{l}{ Weekly intervals } & Mean \\
& W1 & W2 & W3 & \\
Lufenuron 5\% EC & $4.50 \mathrm{f}$ & $5.00 \mathrm{e}$ & $5.33 \mathrm{e}$ & $4.96 \mathrm{c}$ \\
Bifenthrin 10\% EC & $3.50 \mathrm{~g} 1$ & $4.10 \mathrm{fg}$ & $4.51 \mathrm{f}$ & $4.05 \mathrm{~d}$ \\
Chloropyrifos 40\% EC & $6.50 \mathrm{~d}$ & $6.50 \mathrm{~d}$ & $7.16 \mathrm{~cd}$ & $6.72 \mathrm{~b}$ \\
Lamda-cyhalothrin 2.5\% EC & $2.32 \mathrm{~h}$ & $2.50 \mathrm{~h}$ & $3.30 \mathrm{~g}$ & $2.72 \mathrm{e}$ \\
Control & $7.30 \mathrm{bc}$ & $8.01 \mathrm{~b}$ & $8.83 \mathrm{a}$ & $8.05 \mathrm{a}$ \\
Mean & $5.10 \mathrm{~b}$ & $5.16 \mathrm{~b}$ & $5.70 \mathrm{a}$ &
\end{tabular}

Means followed by different letter $(S)$ are significantly different from each other ( $p \leq 0.05$ ); LSD for Insecticides: 0.4090; LSD for week: 0.3168; LSD for Interaction: 0.7083.

Percent number of dead hearts after $2^{\text {nd }}$ spray: The data (Table 5) revealed that mean percent of dead hearts were highly significant among the treatments. Results showed that the lowest number of dead hearts $(2.72 \%)$ were found in the plot treated with Lambda-cyhalothrin followed by Bifenthrin and Lufenuron with $4.05 \%$, and $4.96 \%$, dead hearts. While the highest number of dead hearts $(8.05 \%)$ were calculated in control plot followed by Chloropyrifos (6.72\%).

The results regarding the effect of times interval on the effectiveness of the treatments showed significant difference. Maximum percent of dead hearts (5.70\%) were recorded on week three while the percent of dead hearts (5.10\%) were calculated on week one and two with non-significant difference between their mean values. The interaction between treatments and times intervals were significant different from each other, (Table 5) showed maximum percent of dead hearts (8.83\%) were observed on week Three in Control plot 
followed by week Two (8.01\%) while minimum percent of dead hearts $(2.32 \%$ and $2.50 \%)$ were found in Lambda-cyhalothrin on week One and two respectively, both with non-significant difference.

Percent number of white heads after $3^{\text {rd }}$ spray: The data showed (Table 6) that mean percent of white heads were significantly different from each other in various insecticides after $3^{\text {rd }}$ treatment application on rice crop. The maximum percent of white heads (11.8\%) were recorded in control plot, followed by Chloropyrifos (10.6\%) with slight difference from Lufenuron (9.8\%), while minimum number of white heads $(7.5 \%)$ were found in plots treated with Bifenthrin $(9 \%)$.

Table 6: Mean percent stem borer infestation, white heads (WH) after $3^{\text {rd }}$ spray application of different insecticides, in JP-5 rice cultivar during summer (4 September, 2020).

\begin{tabular}{llllll} 
Insecticides & \multicolumn{3}{c}{ Weekly intervals } & \multicolumn{2}{c}{ Mean } \\
& W1 & W2 & W3 & W4 & \\
Lufenuron 5\% EC & 13.50 & 11.20 & 9.30 & 5.20 & $9.81 \mathrm{bc}$ \\
Bifenthrin 10\% EC & 13.61 & 10.51 & 8.31 & 3.51 & $9.00 \mathrm{~d}$ \\
Chloropyrifos 40\% EC & 14.50 & 11.80 & 10.09 & 6.01 & $10.61 \mathrm{~b}$ \\
Lamda-cyhalothrin 2.5\% & 10.80 & 8.80 & 7.31 & 3.20 & $7.50 \mathrm{c}$ \\
EC & & & & & \\
Control & 15.51 & 12.51 & 11.01 & 8.20 & $11.80 \mathrm{a}$ \\
Mean & $13.6 \mathrm{a}$ & $11.01 \mathrm{~b}$ & $9.21 \mathrm{c}$ & $5.20 \mathrm{~d}$ &
\end{tabular}

Means followed by different letter (S) are significantly different from each other ( $p \leq 0.05$ ); LSD for Insecticides: 1.0534; LSD for week; 0.8690; LSD for Interaction: N.S.

Results revealed that the effectiveness of treatments on white heads had significant difference in different time intervals (Table 6). Maximum percent of white heads (13.6\%), were calculated on week One, followed by week Two (11\%), while the minimum percent of white heads were observed in week Four (5.2\%).

\section{Effect of different insecticides on 1000-grain weight (g) and grain yield $\left(\mathrm{kg} \mathrm{ha}^{-1}\right)$}

The data (Table 7) showed effect of various insecticides against rice stem borer in number of 1000 grain weight showed statistically variation among the cultivars. Mean maximum Thousand grains weight were calculated in Lambda-cyhalothrin (12.53g) followed by Bifenthrin (12.15g), Lufenuron (11.98g) and Chloropyrifos (11.79g) respectively, where's the minimum Thousand grains weight $(\mathrm{g})$ were found in control plot (11.2).
The data (Table 7) showed the effect of various insecticides against rice stem borer in grains yield $(\mathrm{kg}$ $\mathrm{ha}^{-1}$ ) where observed statistically significant difference from each other in various treatments. The mean maximum grains yield was found in Lambda-cyhalothrin (1875.3 $\left.\mathrm{kg} \mathrm{ha}^{-1}\right)$ followed by Bifenthrin and Lufenuron with 1809.5 and $1806.6 \mathrm{~kg} \mathrm{ha}^{-1}$ respectively, while the minimum grains yield $\left(\mathrm{kg} \mathrm{ha}^{-1}\right)$ were noticed in checked plot $\left(1789.7 \mathrm{~kg} \mathrm{ha}^{-1}\right)$.

Table 7: Effect of different insecticides on 1000-grains weight $(g)$ and Grains yield ( $\left.\mathrm{kg}_{\mathrm{g}} \mathrm{ha}^{-1}\right)$.

$\begin{array}{lll}\text { Insecticides } & \text { Yield } & \\ & \mathbf{1 0 0 0}(\mathrm{g}) & \left(\mathrm{kg} \mathrm{h}^{-1}\right) \\ \text { Lufenuron 5\% EC } & 11.98 \mathrm{~b} & 1806.61 \mathrm{~b} \\ \text { Bifenthrin 10\% EC } & 12.15 \mathrm{ab} & 1809.50 \mathrm{~b} \\ \text { Chloropyrifos 40\% EC } & 11.79 \mathrm{~b} & 1798.53 \mathrm{bc} \\ \text { Lamda-cyhalothrin 2.5\% EC } & 12.53 \mathrm{a} & 1875.30 \mathrm{a} \\ \text { Control } & 11.20 \mathrm{c} & 1789.72 \mathrm{c} \\ \text { LSD } & 0.4317 & 12.125\end{array}$

Means followed by different letter (S) are significantly different from each other $(p \leq 0.05)$.

Table 8: Biological efficacy of various insecticides on the population density of Rice stem borer in JP-5 rice cultivar during summer 2020.

$\begin{array}{lll}\text { Insecticides } & \begin{array}{l}\text { Mean Infestation } \\ \mathbf{1}^{\text {st }}, \mathbf{2}^{\text {2d }}, \mathbf{\&} \mathbf{3}^{\text {rd }}\end{array} & \begin{array}{l}\text { Biological efficacy } \\ \mathbf{( \% )}\end{array} \\ \text { Lufenuron } & 5.17 & 28.89 \% \\ \text { Bifenthrin } & 5.03 & 38.07 \% \\ \text { Chloropyrifos } & 6.92 & 14.91 \% \\ \text { Lamda-cyhalothrin } & 3.87 & 52.21 \% \\ \text { Control } & 8.13 & \end{array}$

Biological efficacy of various insecticides on the population density of Rice stem borer in JP-5 rice cultivar during. summer 2020

The data (Table 8) showed the percent biological efficacy of various insecticides (including Lufenuron, Bifenthrin, Chloropyrifos, and Lambda-cyhalothrin) used against rice stem borer. Maximum biological efficacy was observed in plots treated with Lambda-cyhalothrin (52.21\%) followed by Bifenthrin (38.07\%) while minimum Biological efficacy (14.91\%) was recorded in Chloropyrifos.

Yellow stem borer (YSB), Scirpophaga incertulas (Walker), is one of most damaging pests, causes significant loss rice crops. (Kola et al., 2019). Rice stem borers have acquired the status of regular insect pests 
of rice in most of the rice grown area in the state. Scirpophaga incertulas, is a monophagous pest, is regarded as the most serious threat to rice ecosystems in rainfed, low-land, and flood-prone areas (Deka et al., 2010). Yellow rice stem borer alone produces a yield loss of 10 million tonnes globally, and pesticides account for half of all insecticides used in rice fields (Huesing, 2004).

Among our tested rice varieties, we found equal number of similar insect pests; this could indicate the ability of the tested plants' varieties to support a pest population. In the reduction and management, pest resistant varieties have significant role. Resistant cultivars are also effective in the management of insect pests that cause production losses. In the current experiments we studied various rice varieties such as Swati-2014, Basmati-385, Dill Rosh-97, Kashmir Basmati, Fakher Malakand, Lawingi and JP-5. The maximum dead hearts were observed in variety JP5 followed by Lawingi and Dill Rosh-97, which were found to be susceptible varieties. These results were in consistent with the results of Khan et al. (2003); and Shah et al. (2008) stated that the most susceptible rice varieties against rice stem borers are JP-5 and Lawingi under field conditions at DI Khan, also Fakher Malakand was found to have the least dead hearts and white heads. Additionally, Zhu et al. (2002) further supported these results by exploring that used resistant varieties of rice made hindrance to the spreading of rice stem borers and that resistance was due to the two factors i.e. the larger leaf blade size and smaller vascular bundles of these varieties. Furthermore, the findings of Padhi and Sen (2002) were quietly matched, they found that slender, tough and hard stems with narrow piths are the attributes of non-preference wild type of rice varieties. Like that, Padhi (2004) who compared the resistant with susceptible varieties and found that the characteristics like lower borer infestation, the survival of larva, with the increase sugar and phenol content are of tolerant varieties.

The result showed significant effect on rice stem borer in different rice varieties in grain yield. The maximum grain yield was detected in a variety Fakher Malakand whereas the lowest grain yield was recorded in JP-5 followed by Lawingi and Dill Rosh-97. The experimental outputs were parallel with the research work of Rajput et al. (2004) who found that compare to susceptible cultivars some resistant cultivars have high production of rice. Similar findings were also observed by Mamoon-ur-Rashid et al. (2013) described that in fine variety (Basmati-283) they found more unfilled grains. Further evidence of these results were given by Shafique et al. (2000) who concluded that the varieties of rice like IR6-20, IR8-151, IR6-25-1, B/94 and IR6-25 were significantly stable against the infestation of rice stem borers and have high production per hectare. These outcomes are in conformity with Soundarrajan (2020) who documented that the stem borer causes considerable damage and decreases yield in both Rabi and Kharif crops of rice. The host plant resistance and development of the durable resistant cultivars can deliver the best alternative to other management approaches. Results of our experiments showed that Fakher Malakand could be the best variety in combating against the rice stem borer infestation.

In Pakistan rice stem borer is mainly controlled through different chemicals, also with the mean of other alternative source likely through the microbial and plant based extraction. However, as per the findings of Islam et al. (2013) stated that among all types of control measures against rice stem borers, the use of chemicals showed considerably satisfactory results. but the use of such chemicals with other bioactive compounds could produce significant results in order to mitigate the devastation produce by rice stem borers.

The population density of rice stem borer showed significant variation among the synthetic insecticides. Results revealed that compare to other insecticides, Lambda-cyhalothrin showed better effectiveness against rice stem borer. Similar findings are confirmed with Shyamrao and Raghuraman (2019) who investigated that Lamda cyhalothrin 5\% EC was proved to be the best effective insecticide against stem borer. These findings are also in line with Hassan (2017) who concluded that the chemical insecticide Lamda Cyhalothrin 5\% EC showed the best efficacy to control the population of rice stem borer. This finding was further supported by Seni and Naik (2017) who observed that the Lamda Cyhalothrin 5\% EC was significantly effective in reducing the infestation of $S$. incertulus and thus.

Minimizing the onset of white heads and dead heads considerably than by other treatments. These outcomes are in consistent with Chakraborty and Deb 
(2011) who revealed that Lambda-cyhalothrin reduced the population density of rice stem borer.

Lamda Cyhalothrin 5\% EC was followed by Chloropyrifos $40 \% \mathrm{EC}$ insecticide. The results revealed that Chloropyrifos $40 \% \mathrm{EC}$ showed better efficacy as compared to Bifenthrin10\% EC and Lufenuron 5\% EC. The findings are Similar to Prasad et al. (2010) who investigated that the Chloropyrifos $40 \% \mathrm{EC}$ was the best insecticide to reduce the onset of dead heads and white heads during the panicle formation stage caused by a stem borer, similarly Khan et al. (2005) who conducted a study and conclude that Chloropyrifos $40 \% \mathrm{EC}$ is effective against rice stem borer.

Plot treated with Lambda-cyhalothrin 5\% EC gives the highest yield compared with other insecticides. This result is parallel with the research study of $\mathrm{Sa}$ chan et al. (2018) who described that Lambda-cyhalothrin 5\% EC is a useful insecticide and reducing the infestation of stem borer and increasing the yield compared with other treatments. Similar results were also obtained by Seni and Bhima (2017) who reported that the Lambda-cyhalothrin 5\% EC gives high grain yield, which is due to low infestation of rice stem borer and healthier stems. Lamda Cyhalothrin 5\% EC was followed by Chloropyrifos 40\% EC insecticide. The results revealed that Chloropyrifos $40 \%$ EC showed better grain yield as compared to Bifenthrin 10\% EC and Lufenuron 5\% EC The findings are Similar to Firake et al. (2010) who found that the Chloropyrifos $40 \% \mathrm{EC}$ was the best insecticide to reduce rice stem borer to get maximum paddy yield; Similarly, Khan et al. (2005) who observed that the Chloropyrifos 40\% EC was an effective chemical to control the attack of stem borer for better yield per acre.

\section{Conclusion and Recommendation}

From the current experiments the following conclusions were made. Fakher Malakand variety showed significant resistance to rice stem borer and give high grains yield among the other varieties. Maximum infestation of rice stem borer was recorded in JP-5 variety. Lamda Cyhalothrin 5\% EC was recorded as the most prominent to reduce the rice stem borer population Lamda Cyhalothrin 5\% EC has a positive effect on the yield of rice crops.

For higher yield and lowest stem borer infestation, the Fakher Malakand variety is recommended for cultivation in Swat area. Lamda Cyhalothrin 5\% EC should have applied to rice varieties for effective management of rice pest infestation especially rice stem borer.

\section{Acknowledgements}

We acknowledge staff of Agricultural research Institute Mingora Swat, for providing sufficient space and resources to undertake the research activities.

\section{Author's Contributions}

Hussain Ali: Conduct the experiment.

Shahid Sattar Khan and Fazal Maula: Designed the experiment, technical and language checked.

Said Hussain Shah: Analyzed data and wrote the manuscript.

Misbah Uddin: Revised the manuscript.

\section{Conflict of interest}

The authors declare that they have no conflict of interest.

\section{Reference}

Abhinandan, Y. and P.K. Gupta, 2020. Evaluation of new insecticide molecules against rice yellow stem borer Scirpophaga incertulas Walker (Pyralidae: Lepidoptera) under Faizabad Condition. Int. J. curr. microbiol. App. Sci., 9(4): 2772-2777. https://doi.org/10.20546/ ijcmas.2020.904.327

Abro, G.H., T.S. Syed, A.H. Shah, J. Cui, M. Sattar and M.S. Awan. 2013. Efficacy and economics of different insecticides against stem borers, Scirpophaga incertulas (Walker) in rice crop. Pak. J. Zool., 45 (4): 929-933.

Ahmad, N., M.H. Khan, M. Tofique and I. Ruaf. 2011. Insect pest management of B.t cotton through the manipulation of different ecofriendly techniques. Nucleus, 48(3): 249-254.

Alvi, S.M., M.A. Ali, S.U. Chaudhary and S. Iqbal. 2003. Population trends and chemical control of rice leaf folder (Cnaphalocrocis medinas) on rice crop. Int. J. Agric. Biol., 5: 615-617.

Bashir, K., H. Tayyab, F. Tahira, L. Zakia, S.A. Mehdi and R. Sheikh. 2004. Field evaluation and risk assessment of transgenic indica basmati rice. Mol. Breed., 13: 301-312. https://doi. org/10.1023/B:MOLB.0000034078.54872.25 
Behura, N.P.L.F. Sen and M.K. Kar. 2011. Introgression of yellow stem borer (Scirpophaga incertulas) resistance gene, into cultivated rice (Oryza sp.) from wild spp. J. Ind. Agric. Sci., 81: 359-362.

Catindig, J.L.A., G.S. Arida, S.E. Baehaki, J.S. Bentur, L.Q. Cuong, M. Norowi, W. Rattanakarn, W. Sriratanasak, J. Xia and Z. Lu. 2009. Situation of plant hoppers in Asia, In planthoppers: new threats to the sustainability of intensive rice production systems in Asia. Los Banos, Int. Rice Res. Institute, Philippines, 191-220

Chakraborty, K. and D.C. Deb. 2011. Extent of suppression of leaf folder, Cnaphalocrocis medinas, Guan. Population by some selected insecticides in the field of scented local paddy cultivar Tulaipanji at Raiganj, Uttar Dinajpur, West Bengal, India. Int. J. Plant Anim. Environ. Sci., 1: 142-149.

Chakraborty, K. 2009. Incidence of major insect pests of paddy in relation to climatic conditions and cultural practices: a study at Raiganj, Uttar Dinajpur, West Bengal (Doctoral dissertation, University of North Bengal).

Daware, D.G., P.P. Ambilwade, R.J. Kamble and B.B. Bhosle. 2011. Bio-efficacy of insecticides against sorghum shoot fly, Atherigona soccata (Rondani). Indian. J. Ent., 73(3): 227-229.

Deka, S. and S. Barthakur. 2010. Overview on current status of biotechnological interventions on yellow stem borer, Scirpophaga incertulas (Lepidoptera: Crambidae) resistance in rice. Biotechnol. Adv., 28(1):70-81. https://doi. org/10.1016/j.biotechadv.2009.09.003

Divya, D., K.R. Madhavi, M.A. Dass, R.V. Maku, G. Mallikarjuna, R.M. Sundaram. 2018. Expression profile of defense genes in Rice lines pyramided with resistance genes against bacterial blight, fungal blast and insect gall midge. Rice (N Y), 11: 40. https://doi. org/10.1186/s12284-018-0231-4

Duke S.O and S.B. Powles. 2008. Glyphosate: a once-in-a-century herbicide. Pest. Manage. Sci., 64: 319- 325. https://doi.org/10.1002/ ps.1518

Firake, D.M., R. Pande and A.K. Karnatak. 2010. Evaluation of microbal and some chemical insecticide against yellow stem borer and leaf folder of rice. J. Insect Sci., 23(2): 150-153.

G.H. Abro, T.S. Syed, A.H. Shah, J. Cui, M. Sattar and M.S. Awan. 2013. Efficacy and economics of different insecticides against stem borers, Scirpophaga incertulas (Walker) in rice crop. Pak. J. Zool, 45 (4): 929-933.

Hashmi, A.A. 1994. Insect pests of paddy crop. In A.A. Hashmi (Ed.). Insect pest management: cereal and cash crops.PARC,Islamabad,pp.1-61.

Hashmi, A.A. 1994. Insect pest of paddy rice. In: Insect pest management of cereal and cash crops. Pakistan Agricultural Research Council, Islamabad. pp. 1-59.

Hasan, M.F. 2017. Effectiveness of granular insecticides on insect Pests management in three Aman rice varieties (Doctoral Dissertation, Department of Entomology, Sher-e-Bangla Agricultural University, Dhaka).

Hossain, S., H.M.D. Maksudu and R.J. Jamilur. 2015. Genetic Variability, Correlation and Path Coefficient Analysis of Morphological Traits in some Extinct Local Aman Rice (Oryza sativa L). J. Rice Res., 3:158. https://doi. org/10.4172/2375-4338.1000158

Huesing J. 2004. English L. The impact of Bt Crops on the developing world. Ag. Biol. Forum., 7(12):84-95.

Islam, M.S., S. Das, K.S. Islam, A. Rahman, Huda, M.N. and Dash, P.K. 2013. Evaluation of different insecticides and botanical extracts against yellow stem borer, Scirpophaga incertulas in rice field. Int. J. Biosci., 3(10): 117-125. https://doi.org/10.12692/ijb/3.10.117-125

Khan, M., A.U.R. Saljoqi, A. Latif and K. Abdullah. 2003. Evaluation of some rice varieties against rice stem borer. Asian J.Plant Sci.,2(6):498-500. https://doi.org/10.3923/ajps.2003.498.500

Khan, R.A., J.A. Khan, F.F. Jamil and M. Hamed. 2005. Resistance of Different basmati rice varieties to stem borers under different control tactics of IPM and evaluation of yield. Pak. J. Bot., 37(2): 319-324.

Kola, V.S.R., R. Pichili, A.P. Padmakumari, S.K. Mangrauthia, S.M. Balachandran and M. S. Madhav. 2019. Knockdown of acetylcholinesterase (AChE) gene in rice yellow stem borer, Scirpophaga incertulas (Walker) through RNA interference. Agric Gene, 11, p.100081. https://doi.org/10.1016/j. aggene.2019.100081

Krips, O.E., P.W. Kleijn, P.E.L. Willems, G.J.Z. Gols and M. Dicke. 1999. Leaf hairs influence searching efficiency and predation rate of the 
predatory mite Phytoseiulus persimilis (Acari: Phytoseiidae). Ecol. Evolut. Acari., 23(1):119131. https://doi.org/10.1007/978-94-0171343-6_29

MNFSR. 2019-2020. Agric. statistics of Pakistan. Ministry of national Food security and Res. Agric. Div. (Econ. Wing) Govt. Pakistan.

Oko, A.O., B.E. Ubi, A.A. Efisue and N. Dambaba. 2012. Comparative analysis of the chemical nutrient composition of selected local and newly introduced rice varieties grown in Ebonyi State of Nigeria. Int. J Agric., 2(2):16-23. https://doi. org/10.5923/j.ijaf.20120202.04

Padhi, G. and P. Sen. 2002. Evaluation of wild rice species against yellow stem borer (Scirpophaga incertulas). J. App. Zool. Res., 13(23): 147-148.

Parvez,A.,I.haq and M.Ashfaq.2000. Some studies on the physico-morphological characters contributing toward resistance in some maize cultivars against stem borer. Pak. J. Agric. Sci., 37(1): 178- 180.

Prasad, S.S., P.K. Gupta and U.S. Yadav. 2010. Comparative efficacy of certain new insecticides against yellow stem borer, Scirpophaga incertulas (Walker) in semi-deep water rice. Research on Crops. J. Entomol. Zool. Stud., 11(1): 91-94.

Rajput, A.A., M. Sarwar and M. Toufiq. 2004. Varietal screening of different rice genotypes against infestation of rice stem borer. National Conf. Agri. Animal Sci. Sind Agric. Uni. Tandojam. pp. 61.

Sachan, S.K., A.K. Kashyap, S. Ritesh, K.D. Verma and H.R. Singh. 2018. Efficacy of some novel insecticides against yellow stem borer, Scirpophaga Incertulas (Walker) in Basmati Rice J. Pharma. Phytochem. SP1: 195-197.

Sagoo, A.G., M. Aslam, A. Hussian, E. Ahmed, I. Bakhash and M. Irshad. 2012. Bio-Economic response of autumn sugarcane to soil variation, npk management and planting geometry under arid climate. Int. J. Sci. Res., 3(8): 2319-7064.

Mamoon-ur-Rashid, M., M.K. Khattak, M.A. Aftab Momin, R. Bibi and A. Latif. 2013. Performance of different rice cultivars and insecticides against Tryporyza Incertulas (Walker) and Cnaphalocrocis Medinalis (Guenee). Pak. J. Agric. Sci., 50(4): 625-629.

Renuka, P., M.S. Madhav, A.P. Padmakumari, K.M. Barbadikar, S.K. Mangrauthia, K.V.S. Rao, S.S. Marla and V. Ravindra Babu. 2017. RNAseq of Rice Yellow Stem Borer Scirpophaga incertulas Reveals Molecular Insights During Four Larval Developmental Stages. G3 Genes Genomes Genetics. 7: 3031-3045. https://doi. org/10.1534/g3.117.043737

Sarwar, M. 2011. Effects of zinc fertilizer application on the incidence of rice stem borers (Scirpophaga species) (Lepidoptera: Pyralidae) in rice (Oryza sativa L.) crop. J. Cereals Oilseeds, 2(5): 61-65.

Seni, A. and B.S. Naik. 2017. Efficacy of some insecticides against major insect pests of rice, (Oryza sativa L). J. Entomol. Zool. Stud., 5(4): 1381-1385. https://doi.org/10.33307/ entomon.v43i4.405

Shafique, M., M. Ashraf, M. Bux and M. Tofique. 2000. Screening of rice genotypes for resistance to stem borers. Pak. J. Zool. 32(5): 135-137.

Shah, S.M.A., H. Rahman, A. Rahman, F.M. Abbassi, I.H. Khalil and A. Ali. 2008. Characterization of wild rice species in response to leaf folder. Sarhad. J. Agric. 24(11): 69-74.

Shyamrao, I.D. and M. Raghuraman. 2019. Bioefficacy of insecticides against yellow stem borer (Scirpophaga incertulas Walker) in rice ecosystem of Varanasi region. J. Pharm. Phy. Toch., 8(2):301-304.https://doi.org/10.20546/ ijcmas.2019.806.288

Skamnioti, P. and S. J. Gurr. 2009. Against the grain: safeguarding rice from rice blast disease. Trends Biotechnol., 27: 141- 150. https://doi. org/10.1016/j.tibtech.2008.12.002

Soundararajan. R.P. 2020. Mass culturing of rice yellow stem borer, Scirpophaga incertulas W. (Crambidae; Lepidoptera). J. Entomol. Zool Stud., 8(3): 891-895.

Steel, R.G.D. and J.H. Torrie, 1980. Principles and procedures of statistics. McGraw Hill Book. Co. Inc., New York, 336-6.

Yarasi, B., V. Sadumpati, C.P. Immanni, D.R. Vudem and V.R. Khareedu, 2008. Transgenic rice expressing allium sativum leaf agglutinin (ASAL) exhibits high level resistance against major sap-sucking pests. J. BMC Plant Biol., 8(33): 102-115. https://doi.org/10.1186/14712229-8-102

Zhu, Z.P., A. Morromeo and M.B. Cohen 2002. Comparison of stem borer damage and resistance in semi-dwarf indica rice varieties and prototype lines of a new plant type. Field Crop Res., 75(1): 37-45. https://doi.org/10.1016/ S0378-4290(02)00004-7 